\title{
Mini-Miracles:
}

\section{Transformations of Self from Consumption of the Lourdes pilgrimage}

\author{
Leighanne Higgins, Lancaster University Management School, UK \\ Kathy Hamilton, Strathclyde Business School, UK
}

Submission: December 2014

Revision: May 2015

Accepted: May 2015

Send correspondence to Leighanne Higgins, Department of Marketing, Lancaster University Management School (LUMS), Charles Carter Building, Bailrigg, Lancaster, LA1 4YX, UK, telephone: +44 (0)152410096 (l.higgins@lancaster.ac.uk); Kathy Hamilton, Department of Marketing, Strathclyde Business School, University of Strathclyde, Sir William Duncan Building, 16, Richmond Street, Glasgow, Scotland, G1 1XQ, UK, telephone: +44 (0)141 5483240 (kathy.hamilton@strath.ac.uk). 


\title{
Mini-Miracles:
}

\section{Transformations of Self from Consumption of the Lourdes pilgrimage}

\begin{abstract}
This paper explores transformations of self through pilgrimage consumption. A three year ethnographic study of Lourdes, one of the largest Catholic pilgrimage destinations, reveals the concept of "mini-miracles" to refer to those miracles that occur in and are important to an individual's life, but are unlikely ever to be officially deemed as miracles in the eyes of the church. Mini-miracles transform selves and in turn draw pilgrims annually and recurrently to consume the Lourdes pilgrimage experience. The findings reveal the existence of three forms of subjectively experienced mini-miracles: physical, social and peaceful, each of which act as intangible word-of-mouth consumption drivers to the Lourdes pilgrimage. Lourdes, as a business institution, should capitalize on the word-of-mouth mini-miracles shared amongst consumers as a means of building and maintaining stronger networks and relationships within Catholic/ Christian communities at both the national and local level.
\end{abstract}

Keywords: Sacred Consumption, Transformation, Pilgrimage, Miracles, Ethnography 


\section{Mini-Miracles: Transformations of Self from Consumption of the Lourdes pilgrimage}

Caroline, a nurse in Ireland, was asked to volunteer to care for sick pilgrims in Lourdes but with a young family including a toddler going through toilet training she felt this would be impossible. "I could not leave that responsibility to my mum and husband, and go off to France for a week”. That night her child slept right through, "a completely dry night", which she believed to be "a fluke”, but the next nights were the same and that was it: her child was toilet trained. As Caroline shared, "bang went that excuse, so I blamed not having the finances”. However, a week or so later she moved some boxes and out fell an envelope with US dollars from a trip she had made a few years previously. She exchanged the money and "you will never guess what, it calculated, I kid you not, to the exact penny to the amount I needed to go to Lourdes”. She then asked her mother to look after her children so that she could volunteer in Lourdes. Initially her mum refused, telling Caroline she could not possibly leave them and go "frolicking” in France, so as Caroline put it - "that was that”. However, something transformed her mother's thinking and the next day she visited Caroline and told her, "that was unfair of me, if you want to go and help people who desperately need help, who am I to stop that? Of course, go.” So Caroline came to Lourdes and has continued to volunteer for over twenty years. Caroline links a "major" miracle in her life to Lourdes: after years of alcohol addiction her husband suddenly quit, a transformation that Caroline completely attributes to her years of coming to Lourdes and begging Our Lady for the addiction to cease (Based on researcher field notes).

In 1858, in the small and derelict village of Lourdes in France, a series of apparitions seen by fourteen year old peasant girl, Bernadette Soubirous, of a lady believed, and 
authenticated in 1862 by the Catholic Church, to be Mary, the Mother of Jesus Christ, led to the growth of one of the biggest Catholic sanctuaries and pilgrimage sites in the world (Fargues, 2011). Pilgrimages are an important context to explore transformation because they are defined as transformational journeys (Gesler, 1996). The limited marketing and consumer research on pilgrimage tends to focus on the "place-directed marketplace" (Scott and Maclaren, 2013) surrounding the pilgrimage site, or the taking of goods away from the pilgrimage site (Kedzior, 2013; Moufahim, 2013). In other words, prior research privileges the tangible good and many questions remain unanswered about intangible pilgrimage experiences. This paper is therefore focused on this research gap and its aims are twofold. The first aim is to better understand the key intangible drivers that draw pilgrims annually and recurrently to consume the Lourdes pilgrimage experience. The second aim is to understand how these drivers encourage a transformation of the self.

Lourdes is a place of divine intervention where transformations are attributed to factors beyond the individual. Respondents regularly share their personal Lourdes story which explained what had initially brought them to Lourdes. The opening account from Caroline offers one example and, in common with other respondent narratives, suggests elements of mystery and magic. Popular understandings of such transformation in pilgrimage sites are often associated with miracles, yet since 1858 only 69 recorded miracles have been authenticated and aligned with Lourdes. Nonetheless, the findings from this ethnographic study reveal that the miracle narrative remains central to the Lourdes consumption experience. The key theoretical contribution of this paper is to introduce the concept of minimiracles to refer to those miracles that occur in and are important to an individual's life, but are unlikely to be officially deemed miracles in the eyes of the church.

The paper starts with a brief overview of the Lourdes context, which is followed by a discussion of academic research in the areas of pilgrimage, transformation and miracles. The 
findings of an interpretive ethnographic methodology reveal the existence of three forms of subjectively experienced mini-miracles: physical, social and peaceful, which act as intangible word-of-mouth consumption drivers to the Lourdes pilgrimage. This is important because it raises a number of implications for religious marketplaces which need to be branded and marketed like other products and services in order to maintain their relevance within contemporary culture (Einstein, 2008).

\section{Lourdes: A contextual overview}

Since the apparitions of 1858, the village of Lourdes has grown to become the second largest tourist destination in France and the third largest Catholic pilgrimage destination (Fargues, 2011). With a week’s pilgrimage in Lourdes costing £700-£1000 it may seem surprising that this expensive week is consumed recurrently and annually by many pilgrims over their lifetimes. However, for the consumers of this experience, the costs are outweighed by their need to search for hope and spiritual renewal, and even for a potential miracle. Lourdes is a "vast religious complex" (Fargues, 2011, 65) consisting of three large basilicas and several chapels, as well as two hospitals, a welcome center, a bookshop, two museums, numerous accommodation options and eating places for volunteers, alongside premises for approximately 300 Lourdes employees. The secular town surrounding this complex is equally expansive, with 208 hotels, 100 restaurants and 220 souvenir shops, providing the equivalent of one shop for every 30,000 pilgrims to Lourdes (Fargues, 2011, 65). Consequently, Lourdes, which is seen as a "spiritually based community (SBC)" (Granger, Conduit, Veale and Habel, 2014), has clearly become a restructured consumption scape (Urry, 1995) and a "place directed marketplace” (Scott and Maclaren, 2013) where consumers can consume both the sacred offerings of the Sanctuary and the secular offerings of the Lourdes marketplace. 
The first miracles of Lourdes occurred in 1858, during the time of the apparitions. As the end of the nineteenth century approached, a "miraculous mood" (Harris, 1999, 19) took over at Lourdes, with more and more people claiming to have been miraculously cured of ailments, causing the church to become "notably very concerned" (Fargues, 2011, 189) about the claims. Consequently, in 1883 the Sanctuary of Lourdes established Le Bureau de Contestations Medicales (The Medical Bureau), an official investigative office that uses modern medical diagnosis to check the authenticity of curing and miracle claims. The authentication of a miracle at Lourdes is not a quick or easy process, as the Catholic Church took from 1989 to 2013 to authenticate the most recent $\left(69^{\text {th }}\right)$ Lourdes miracle. Yet, despite the low number of authenticated miracles, "Lourdes in the popular mind means miracles" (Marnham, 1989, 196). This is partly due to the transformative nature of pilgrimage, as the following literature section of the paper explores.

\section{Literature Review: Consuming Pilgnimage, Transformation, and Miracles}

The marketization of religion (Twitchell, 2005; Haddorff, 2000, Izberk-Bilgin, 2013; McAlexander, Leavenworth Dufault, Martin and Schouten, 2014) has blurred the boundaries between the sacred and the profane. Pilgrimage sites across the world have become "placedirected markets - sites of exchange created by the crowds drawn to a sacred place... [and]

are at least as numerous and certainly as important as those created by marketers or even antimarket promoters” (Scott and Maclaren, 2013, 196). Markets surrounding religious sites are characterized by a plethora of religious trinkets known as "Jesus Junk" (McDannell, 1995; Park and Baker, 2007). These kitsch objects are viewable as "anachronistic, clichéd, derivative, mass-produced, populist and in poor taste” (Turley, 2013, 169), with research attempting to understand these markets by classifying visitors into either pilgrims or tourists according to the extent of their market engagement (e.g., Eade, 1992). This focus on consumer goods aligns with other research on religious consumption surrounding religious 
jewelry (Fernandez and Veer, 2005; Rinallo, Scott and Maclaren, 2013) or clothing influenced by religious beliefs (Sandikci and Ger, 2010). The experiential nature of pilgrimage consumption remains less well understood and this research therefore complements the existing research by focusing on subjective pilgrimage experiences.

The transformatory element of the subjective experience of pilgrims is described in the following definition offered by Gesler $(1996,96)$ :

A pilgrimage entails a journey from one place to another, from one aspect of one's life to another. As a result of this movement, many people experience pilgrimage as a transformation. Religious pilgrimage, in particular, can be viewed as a movement from the profane to the sacred, from everyday life to an encounter with the divine, or from local, conventional religion to a radiant religion experienced in a far-off place.

McCracken $(2008,1)$ suggests, "transformation is a diverse and complicated phenomenon." Transformation within the context of the religious pilgrimage is arguably all the more complex given the involvement of sacred elements that operate beyond the realm of individual agency. In their seminal work, Turner and Turner $(1978,11)$ suggest that as pilgrims draw close to the peak of their pilgrimage experience they receive a "pure imprint of a paradigmatic structure" which provides "a measure of coherence, direction, and meaning to their action.” However, Turner and Turner (1978) largely consider pilgrimage transformation to occur at a communal level as pilgrimage sites give rise to temporal social anti-structural moments of communitas wherein the prevailing social structure of the time is cast off along with considerations of age, gender, and social class. This paper complements this communal perspective by prioritizing the subjective experiences of individual pilgrims. 
McCracken (2008) discusses the idea of different "transformational routines" in relation to "the set of conventions by which an individual is changed... [they] are the processes by which people take on social "shapes of a different kind”' (2008, xxii). McCracken (2008) identifies four routines: the traditional, which refers to the processes of rites of passage, status, meaning the processes through which people will augment their social standing, modernist, relating to processes which aid people to become more mobile both in private and public spaces, and postmodernist processes, which offer multiplicity and fluidity to individuals. McCracken (ibid, xxii) views these routines as being "additive”, as one routine does not "supplant" another. Consequently, all transformations begin in the traditional way and slowly grow, evolve and transform into something more. The routine most relevant to, and evident in, this study is the traditional routine. This is especially so given that this study is investigating a branch of the Catholic Church, an institution often critiqued for its maintenance of 2000 year-old dogmas, and its refusal to conform to $21^{\text {st }}$ century societal norms, thus possessing a traditional "passion for stasis and continuity" (McCracken, 2008, 53). McCracken (2008) also indicates the importance of ritual and myth to traditional transformatory routines.

Many visit Lourdes annually and recurrently over their lifetime, with the pilgrimage becoming a consumption ritual (Rook, 1994). In particular, pilgrimages have an alignment with "rituals of affliction" (Turner and Turner, 1978, 11), a term which refers to rituals that are performed as a means of eliminating ailments, dark forces, bad luck and even death, and which generates the idea of "the economy of salvation” (McDannell, 1995, 140). An economy of salvation involves the exchange of goods, gifts and donations at shrines, chapels and other religious sites as a means of establishing "a series of obligations between those on earth and those in Heaven” (McDannell, 1995, 140). Consequently, for many consumers the Lourdes pilgrimage is a payment for divine intervention to ease their earthly woes. 
Myths are "traditional stories, often concerning the early history of a people, or explaining some natural or social phenomenon, and typically involving supernatural beings or events” (Collins English Dictionary, 1982, 745). This focus on supernatural causes aligns with the objective definition of a miracle which states that it is "beyond the ability of nature to produce” (Larmer, 1988, 6). Similarly, C.S. Lewis (1947/1989, p. 5) defined a miracle as "an interference with Nature by supernatural power" aligning with the Catholic perception of a miracle as being a "sign from God" (Marnham, 1989, 203). For Lewis, however, a miracle does not "break the laws of Nature” (1947/2012, 94), but rather miracles are art forms, plot twists or interferences which "feed new events" (1947/ 2012, 95) into the natural order. Consequently, in interrupting the natural course of events miracles assert more "unity and self-consistency of total reality" (Lewis, 1947/ 2012, 97), becoming "short cuts” (1947/ 2012, 221) enabling the transformation of events or of the self. Lewis (1947/2012) defines miracles to be microcosmic variations of the Grand Miracles performed by Jesus Christ. Within the context of Lourdes this would apply to events that have been officially authenticated by the Catholic Church, including the apparitions of 1858 and the 69 recorded miracles relating to the curing of pilgrims since then. Consequently the miracles and magic of Lourdes are regarded as true gifts from divinity.

The subjective use of the term miracle places a greater emphasis on the observer's reaction to the event in terms of the personal impact it has on his/her life than on the event itself (Larmer, 1988). The present study focuses on subjective and emic understandings of miracles as defined by its respondents rather than those understandings that are officially approved. In particular, the focus on the subjective understanding of miracles in the transformation process extends previous work on transformational routines. This is done by introducing the concept of the mini-miracle to refer to those miracles that occur in and are important to an individual's life, but are unlikely ever to be officially deemed as miracles in 
the eyes of the church. Specifically, these are transformations that offer social, physical and peace of mind benefits to the individual. The telling and retelling of such myths entrench them into "cognition and culture", transforming the myth into a "permanent way of thinking" (McCracken, 2008, 42) so that they become "stories stamped large with social approval" (Burridge, 1960, 250). Previous work suggests that an analysis of stories surrounding place experiences can reveal how destination myths are interpreted (Hsu, Dehuang and Woodside, 2009), as is the case in this study where findings reveal the narrative of miracle has become synonymous with the Lourdes pilgrimage site.

\section{Method}

Following the lead of previous consumer research (Arnould and Price, 1993; Belk, Wallendorf and Sherry, 1989; Celsi, Rose and Leigh, 1993; Peneloza, 1994; Peneloza, Thompson, Schouten, Sampath, Meamber, 1998; Schembri, 2009; Schouten and McAlexander, 1995; Scott and Maclaren, 2013) and pilgrimage scholars (Morinis, 1992; Reader and Walter, 1993; Turner and Turner, 1978), the present study adopted an interpretive ethnographic methodology. The three-year ethnography utilized a "diversified toolkit" (Sherry, 1998, 4) by including the methods of participant observation and in-depth interviewing, "privileging” both what consumers "say” and “do” (Peneloza et al., 1998, 352). The researcher participated in over eight weeks' immersion at Lourdes during the high season (spring/ summer) alongside numerous days at subsidiary shrines throughout the UK and Europe. As a means of fully engaging with and understanding the Lourdes consumption narrative, the fieldwork took various formats. Visits were organized independently through a volunteering program and as a week-long pilgrimage with an organized group from Scotland, enabling the researcher to undertake multiple roles (Hamilton, Dunnett and Downey, 2012) as volunteer, pilgrim and researcher. The data collected on site amounted to 200 pages of collated field-notes and approximately 3000 videos and photographs. 
The research was an iterative process with an ongoing analysis shaping the back-andforth movement between participant observation and interviewing (Spiggle, 1994). The researcher completed three visits comprising five weeks of fieldwork at Lourdes prior to conducting the in-depth interviews. The connections made during these visits proved useful for recruiting interviewees in line with a purposeful sampling strategy (Lincoln and Guba, 1985). Other interviewees were recruited with the help of two employees within the local Archdiocese (Catholic community) who acted as gatekeepers. In total, twenty-three respondents participated in semi-structured interviews lasting between 30 minutes and four hours, with an average duration of 2.5 hours and producing over 1000 pages of transcription. The sample included males and females ranging in age from 17 to 93 (Table 1). All the respondents were native to fluent English speakers. Twenty-one of the respondents were practicing Catholics and it is these respondents who are the focus of this paper. The majority of the respondents were recurrent consumers of Lourdes (e.g., Patricia, who first volunteered at Lourdes in 1949 and at the time of interview, aged 93, continues to volunteer annually), while those who had only visited once expressed the intention to return. Some interviews were conducted individually, and others were undertaken in groups or in couples. Group interviews were conducted with family members or close friends who had consumed Lourdes together as a means of building a deeper and more holistic understanding of group dynamics.

In order to trace the Lourdes consumption narrative more fully, respondents were either interviewed multiple times or prompted to provide informal updates. For example, the two first-time consumers of Lourdes (Danielle and Frances) were interviewed ahead of, and then following, their experiences. Both the field notes drawn from the fieldwork in Lourdes and the literature were used to identify the interview themes. The interviews each began with questions related to the interviewees' religious background and the pilgrimages they had undertaken. The main discussion then centers on their experiences at Lourdes with questions 
focusing on the following themes: motivations for pilgrimage to Lourdes, meanings of Lourdes, memories associated with Lourdes, rituals at Lourdes (religious services, evening processions, prayer, etc.) and places at Lourdes including within the Sanctuary, the surrounding marketplace and the relationship between these Sacred and secular sites. The iterative nature of the research meant that an analysis of the initial interviews uncovered several additional informant-generated themes, including family and miracles, which were consequently added to the interview schedule for further probing.

\section{TABLE 1 HERE.}

In following a hermeneutic approach to the interpretation of data, the goal was to achieve "an understanding free of contradictions” (Arnold and Fischer, 1994, 63). Through iterative analysis (Spiggle, 1994), patterns were identified within and across informants and within and across data sets until a coherent understanding was built. At this stage, the researcher undertook one final week of fieldwork in Lourdes to ensure that the interpretation was valid and that thematic saturation had been reached (Brewer, 1998, Wallendorf and Belk, 1989). At that point the decision was made that no further interviews or fieldwork were required.

\section{Findings: The Narrative of the Mini-Miracle}

Narratives permeate the data in this study; field notes resonate with the Lewisian (1947/2012) grand and objective miracle versus the subjectively experienced "mini-miracle”, with respondents continuously differentiating between the "stereotypical miracle” (Miriam, 
26) and the "wee (small) miracle" (Patricia, 93) or, in other words, "a miracle versus a 'Miracle'” (Maria, 54). However, in contrast to the Lewisian perspective, the respondents have little experience of objective extraordinary miracles (Larmer, 1998); rather, they experience miracles of a more miniature, intimate and personal nature. Although these are inconsequential to the Catholic Church or even to wider society, they are important to the individual and a large driver of the Lourdes consumption experience. Garry and Lilly express this sentiment:

A miracle doesn't always have to be something that you would associate with the kind of traditional 'you're blind and then you can see,' it is wee [small] mini ones that you see every day. (Garry, 26)

I think people have very different perspectives of miracles. Some people expect to go to the baths with a broken leg and come out walking. I think people expect that, but I don't expect that. I think a lot of the time miracles would be for me realistic-I know miracles aren't meant to be realistic - but for instance my uncle had no faith at all, never went to Mass [Church] for 10 years. He then went to Lourdes and came back as a devout Catholic, it changed him. I think God and Lourdes did that to him. (Lilly, 24)

The concept of mini-miracles refers to the small and relatively realistic miracles associated with Lourdes. Consequently a mini-miracle is defined as "a transformation of the individual that brings positive benefits and is attributed to sacred forces beyond individual 
control." Unlike previous miracle theory which highlights the extraordinary power and rare occurrence of miracles, these mini-miracles are less extraordinary (although they are, of course, still crucial to the life of the individual who experiences them) and more frequently experienced. Mini-miracles encountered through Lourdes consumption do not always involve an instantaneous transformation but rather, may stem from a series of individual experiences, as the opening narrative concerning Caroline and the sequence of events which firstly led her to Lourdes reveals. Continued revisits and consumption of the site has eventually led to her major, life-transforming miracle. Many of those encountered over the three year ethnography were keen to share their own examples of mini-miraculous events, thus the miraculous narratives become further entrenched in the wider, Grand Lourdes narrative. However, rather than at a church or community level (Turner and Turner, 1978), these mini-miracles become entrenched at a more personal level. Analysis of these mini-miraculous narratives helps in uncovering thematic similarities and emic understanding reveals the discussion of minimiracles in three distinct ways: physical, social and peaceful.

\section{Physical Mini-Miracles}

Building on the definition of mini-miracles, physical mini-miracles are defined as a transformation of the self that brings positive physical benefits through a restoration of health that is attributed to sacred forces beyond individual control. Such physical miracles often stem from the experience of Lourdes in its entirety; however for many, the ritualistic experience of the Baths is felt to be transformatory. The baths are a sacred ritual at Lourdes, whereby individuals are bathed in Lourdes water and prayed over as a means of asking for divine intervention with afflictions: 
A lady from Paris, she had a daughter who never spoke and had tried all kinds of things, she had heard about Lourdes and came down. And she and her daughter went to the baths and prayed, etc., and on the way back in the car the daughter said "mama..." - she began speaking - now she has to get help and she is making progress. But for them it was this visit, they had got all the medical help beforehand, they were rich people and they had tried everything but then they came down here. Now these kinds of things will never go down, and the healings that we see in people they will never go down [never be authenticated by the Medical Bureau of Lourdes] - but I would call those miracles. (Fr. Brendan, 73)

The preceding interview extract aligns more closely with the objective Lewisian (1947/2012) perspective on microcosmic miracles because of the extraordinary nature of the cure. However, as noted by Fr. Brendan, this would remain a subjective miracle in the eyes of the Catholic Church and wider society. Examples of such extraordinary physical cures are more the exception than the norm in this study, and consequently the remainder of the findings discussion will center on less extraordinary mini-miracles which are more clearly linked to subjective understanding. For example, many respondents such as Garry spoke of miniature physical miracles occurring at Lourdes, with many witnessing the temporal giving of life:

Once we took a sick little girl to Lourdes, and she was brilliant in Lourdes, she was walking about and talking and all that and 
literally the day she went home from Lourdes she never walked or spoke again. Her mum always says that she thinks it's because she was in Lourdes and she had so much energy coming from all the people who were working with her that it kept her going, and then as soon as she went home she just - that was her - she just went on a real downward spiral and she died a couple of weeks later.

(Garry, 25)

The above vignette aligns with the belief many respondents express that the transformative nature of the Lourdes consumption experience often aids sick consumers to return home and face dying. Although it is impossible to know exactly how the experience transformed the life of the little girl discussed by Garry, he believes with certainty that in Lourdes, the place, the people, and the experience in its entirety granted the girl a temporal reprieve from her illness, transforming her to wellness again, however briefly. Equally, his retelling of her story illustrates a transformation in him, as working with terminally ill children is an opportunity "to be part of that kid's life, for kids who are only here for such a short period of time and that gives you all kinds of lasting memories” (Garry, 25). It is therefore clear that the opportunity to imprint, even if only briefly, upon a child and their family is transformational for Garry, imprinting permanently on his own life. This brings to the fore an interesting finding shared by many respondents of this study relating to the secondary consumption of the mini-miracle, whereby consumers do not have to experience the mini-miracle themselves but can instead consume the narrative of the mini-miracle in a secondary way through others' experiences at Lourdes. 
None of the respondents attempt to explain how Lourdes facilitates such physical transformations. Often respondents mention the nebulous "something," pointing towards something inexplicable, something Deistic, which is bringing the miracle to pilgrims, again resonating with the Lewisian (1947/ 2012) perception of a supernatural alignment with miracles. Consumer agency is often understood as an individual's ability to act in their own best interests. In the examples offered in this section, any form of earthly intervention would have little impact on the physical outcome. By deciding to make the pilgrimage to Lourdes these consumers put their trust in a higher being to act in their interests. The following sections discuss the emic themes of social and peaceful mini-miracles, both of which relate to the emotional and holistic transformation of the self.

\section{Social Mini-Miracles}

Building on the definition of mini-miracles, social mini-miracles are defined as a transformation of the self that facilitates a more confident and holistic sense of self for the individual within social settings, and they are attributed to sacred forces which lie beyond individual control. Indications of social mini-miracles are apparent from discussions with brothers Garry and Jacob $(25,27)$ during which Garry shares how his brother Jacob had undergone something of an "evolving sense of identity” (Tiwsakul and Hackley, 2012, 491) which Garry believes stemmed from Jacob’s initial Lourdes experience. Garry shares that Jacob had always been “quiet and shy and didn’t speak much” but that he "noticed him getting more and more confident every time he returned from Lourdes”, and also that he was shocked when on travelling to Lourdes with Jacob one year he witnessed him "standing on tables, up playing guitar and singing to all the kids we volunteered with, but also with like the other fifty, sixty people who are just there in the café. (Garry looks at Jacob and asks) Is that a miracle-I don’t know? A social miracle perhaps?” (Garry, 25). The confidence gained through his consumption of the Lourdes pilgrimage experience was therefore seen to have 
permanently transformed Jacob into a more outgoing, confident individual. Similar transformative miracles were experienced by many young consumers of the Lourdes experience:

When I first went to Lourdes a few years ago, I was really quite shy; I didn't really integrate well with new people. I've always felt really, really awkward and I became kind of introverted a bit. I didn’t really like to put myself out there whereas my whole approach to that now is if I feel kind of awkward in a social situation, I just fling myself in, because if you're feeling awkward, you'll find most folk are also feeling the same, you know what I mean? That was one of the things I really liked about the Lourdes youth group; it's kind of helped me come out of my shell a bit more. (Matthew, 22)

People always said "oh Lourdes changes you, it makes you really happy, it makes you a good person”- but I did not quite agree. I thought that Lourdes does not change you, the experience of Lourdes and the work that you do and the people that you meet, that does not change you but it makes you like the person that you should be, and for a long time I had forgotten that feeling that I had in Lourdes...I had been very badly bullied at school so I was very, very low, I felt that I really had to almost quieten down my personality. I think if you were to ask people from school that knew me they would say that I was very quiet, that I was quite subdued but in a way that was because I thought, well I know that I am quite chatty, I know that I am quite loud and happy but I cannot 
afford to show people that because I keep getting it thrown back at me so I sort of had it there, I did not ever lose that but I was not able to use that part of myself. So, honestly Lourdes did not transform me, I did not come back like a new girl, but I came back knowing what I wanted and knowing how I could feel... it gave me the opportunity to use that quietened side of me, I was like, this is brilliant, I can do this, I can talk to people, I can make these jokes and things like that, that I could never really do before. (Danielle, 18)

The shared consumption experience with fellow youths at Lourdes enabled a confidence transformation for Matthew, and the release of a hidden side to Danielle that had been suppressed because of years of bullying at school. However, the confidence building shared by many youth respondents does not indicate a complete transformation of the internal, “authentic self” (Belk, 1988), but rather points to a release of "hidden” or "unknown” identities resulting in a more holistic "coherent” sense of self (Ahuvia, 2005). It is unsurprising that a powerful experience such as those which many have at Lourdes would have such a transformative effect on young people, as they are at crucial and liminal points in their lives. Although from a Lewisian perspective, such transformation would eventually have taken place in their everyday lives and trajectories (since miracles are merely short-cuts which accelerate the Natural order (Lewis, 1947/2012)), the adolescent informants in this research clearly attribute the Lourdes pilgrimage experience and their consumption of it as the catalytic factor bringing about their transformed sense of self. McCracken (2008) discusses traditional transformational routines as linked to rites of passage, and in consuming the Lourdes pilgrimage experience, social mini-miracles facilitate the transformation of the 
adolescent self. Accordingly this transformation becomes entrenched in their own personal Lourdes narrative that they share over and over again with those whom they meet, thereby encouraging future pilgrims, especially other youths, to consume Lourdes too. Therefore, unlike previous consumer research which has found transformations to be gradual and temporal (Schouten and McAlexander, 1995), the experience of the Lourdes pilgrimage acts as a "short-cut" (Lewis, 1947/ 2012, 212) enabling a more rapid and permanent form of transformation to occur.

\section{Peaceful Mini-Miracles}

Building on the definition of mini-miracles, peaceful mini-miracles are defined as a transformation of the self that facilitates the greater peace of mind and the greater ability to cope with difficult circumstances that are attributed to sacred forces beyond individual control. Many respondents share the belief that the Lourdes consumption experience enables them to "find peace" (Miriam, 25), for example, Christine (63) suggests that, "last year after speaking to Father Hammond at Lourdes my worries were able to, maybe not evaporate, but to leave me. That was a major miracle in my life.” Sr. Anne (47) refers to such relief from prior anxiety as "the miracle of an internal grace" which she contrasts with "the external miracle" which is more visible to others: "unlike the external miracle which is always of its nature very dramatic, I think the internal ones can be undramatic but almost more powerful because your mind is a harder nut to crack really than your body very often.” Sr. Anne continues by offering the following example:

My mum had experienced something because she went when she was about 20 and my mum is profoundly deaf and she started to go deaf when she was 14-16 and it was affecting her schooling and stuff and her hearing obviously. Anyway by the time she was 20 she was really very, very deaf and she was really cut up [upset] 
about it and in those days you had hearing aids, massive boxes hanging around your neck and stuff, and she hated it so much and went to Lourdes. She was working in the baths, and her friends immersed her fully into the bath, like totally plunged the whole of her in, and after that experience she had in Lourdes she no longer felt bad about it, she never got her hearing back - she is deaf to this very day and without her two hearing aids she hears absolutely nothing. But it never was an issue for her then, she had total acceptance of it. (Sr. Anne, 37)

From an objective perspective it may be argued that this example has no miraculous quality, as the underlying medical condition is unchanged. However, from the subjective perspective of the respondent, an important transformation occurs at Lourdes that leads Sr. Anne’s mother to accept her hearing impairment. Lisa makes a similar point about how Lourdes can help people deal with difficult situations. In the extract below she discusses how a father in her pilgrimage group learns to accept his daughter's diagnosis of cancer while he was in Lourdes:

I haven’t witnessed a physical miracle. But peace of mind, like when I was saying about that wee girl Stacey; her dad was just absolutely distraught and he couldn't understand why this was happening to his wee [small] girl. But by the end of that week he was just like “God wouldn’t have given me this cross if I couldn’t carry it and yes, you know she's got this, but she's still my baby.” He was an emotional wreck the whole week, but watching him go through that I feel like that's a wee [small] miracle in itself because 
without that he might still be really angry but he learned to let that go. I wouldn’t say I have experienced a physical miracle because I definitely haven't, but I think a lot of people achieve peace of mind with what their lot is in life. (Lisa, 19).

The interview extracts reproduced above illustrate the transformative emotional reversals which occur at Lourdes: from anger, pain, upset to peacefulness, acceptance and hope. This enables consumers to better accept their lot in life, and correlates with the belief from Lochran $(2008,16)$ that, "Lourdes speaks of the healing of the heart more than of the body”. Respondent Peter, a doctor with many years of experience as medical director for a Scottish pilgrimage group to Lourdes, shares such belief in the predominance in an intimate, inner healing. He has witnessed "some, but not many, physical miracles" and instead emphasizes a "global impression of people coming back better as a consequence of the experience” (Peter, 66). Consequently, in contrast to the work of tourism scholars Ross and Iso-Ahola (1991) who find vacation experiences to be aligned with a yearning for escapism, Lourdes consumers seek help, not escape, from their everyday lives, problems and afflictions. Equally, in contrast to the work of Choi and Megehee (2014) in which a physical, external transformation is evident, the peaceful mini-miracle involves an emotional internal transformation, changing consumers of the Lourdes pilgrimage experience for the long-term and for the better in their everyday lives.

\section{Discussion}

Pilgrimage remains central to many religions but research to date has failed to fully investigate the consumption of pilgrimage sites (Scott and Maclaran, 2013, 196), with Moufahim $(2013,17)$ recently calling for research that generates a "better understanding of 
religious markets.” The present paper responds to this gap and aims to better understand the key intangible drivers that draw pilgrims annually and recurrently to consume the Lourdes pilgrimage experience, and to understand how these drivers encourage a transformation of the self. In reaching this aim, the core theoretical contribution is the introduction of the concept of mini-miracles which extends theoretical understanding of miracles beyond the general definition which covers those which are extraordinary and objective. This reveals an intangible consumption driver that leads to a transformation of the self within the religious marketplace. This focus also complements much of the existing pilgrimage theory which tends to privilege communal, as opposed to individual, transformation. The research published to date discusses transformation from a social or group conformity perspective, taking the view that consumers wish society or a group to view them in a particular way and that consumption helps them to achieve this status (Schouten and McAlexander, 1995; Choi and Megehee, 2014), aligning with McCracken ‘s (2008) status transformatory routine. In contrast, this study offers a case where transformation is not status-led but is, in fact, for the self. This extends Granger et al.’s (2014) work by finding Spiritually Based Communities (SBC) to be more complex than mere philanthropy and communal ideals, having room also for both the welfare of others and of the self.

Consumer research discussions often cite the consumption of tangible goods and products such as clothing as a means of self-transformation (Tiwsakul and Hackley, 2012; Choi and Megehee, 2014). Goods and products become extensions and identity builders of the self (Belk, 1988), with self-transformation predominantly viewed as being facilitated by the marketplace. This emphasis on tangible goods is equally evident within research on the religious marketplace (McDannell, 1995, Kedzior, 2013, Moufahim, 2013, Rinallo et al., 2013, Turley, 2013). At Lourdes, however, such transformation is facilitated neither by the marketplace nor the consumer, but rather by the nebulously unknown "something". This is 
the unique selling point (USP) of Lourdes. The miracle narrative is core to this USP because as noted earlier, miracles are often understood within the religion context as events that are beyond explanation and that would not have occurred without "the intentional activity of a supernatural being” (Basinger, 2011, 19). For the respondents here, the inexplicable nature of Lourdes is epitomized by the occurrence of subjectively experienced mini-miracles: instances of transformations of individuals that bring positive benefits and are attributed to sacred forces beyond individual control.

The concept of mini-miracles resonates with Kniazeva and Belk’s (2010) work on consumption and myths. They found "micro-myths" to exist, in contrast to an overarching "mono-myth", discovering that consumers "co-author the myths" to create a brand packaging aligning with their "own individual objectives and desires" (2010, 752). A similar parallel is found here as the "mono-myth" of the Grand objective miracles of Lourdes are "reconstructed" and "reinterpreted" $(2010,752)$ by pilgrimage consumers, resulting in a widespread belief in, and experiencing of, mini-miracles. Thus, the Lourdes miracle narrative evolves to incorporate both the Grand objective miracles of the apparitions and cures, and the subjective mini-miracles experienced by consumers, either themselves or through others.

Mini-miracles transform the self in three ways: physical, social and peaceful. Physical transformations align most closely with the traditional Grand and objective definitions of miracles (Lewis 1947/2012, Larmer, 1988), and involve visible physical benefits such as the restoration of health. The introduction of social and peaceful mini-miracles as a route to transformation extends the existing literature by exploring subjective understandings of miracles. Social transformation facilitates a more confident and holistic sense of self within social settings. Peaceful transformation facilitates a greater peace of mind and a greater ability to cope with difficult circumstances. Each of these forms of mini-miracle is attributed to sacred forces beyond individual control. This makes an interesting point of comparison 
with previous studies in relation to the agency of the consumer throughout the process of transformation. Studies so far on transformation represent the consumer as an active player or even the initiator of the transformation process. For example, Ahuvia's $(2005,180)$ research suggests that the consumption of loved objects can facilitate transformation towards an ideal self, with one example relating to the "self-transformative power of clothing". In this case, the consumer can clearly articulate how the transformation occurs (i.e., through particular clothing choices). In contrast, the transformation of the self that occurs through the consumption of Lourdes goes beyond the individual and is something that cannot be so clearly or easily explained. In fact, none of the respondents attempt to rationalize the minimiracles they encounter; they simply accept them as welcome events which are central to their transformation of self. Thus, while the consumer of Lourdes is not entirely devoid of agency (they have, after all, made the meaningful choice to undertake the pilgrimage), the mini-miracles are believed to be outside their control.

\section{Managenial Implications}

The findings emerging from this three-year ethnographic study reveal a change in the ways in which pilgrims consume the Lourdes experience, with a decline in the numbers of large-scale organized pilgrimage groups alongside an increase in individual and small pilgrimage groups (less than 10 people). The Head of English Chaplaincy at Lourdes, Fr. Brendan, indicates that only $18 \%$ of pilgrims coming to Lourdes today are part of large pilgrimage groups, with one of the largest national pilgrimage groups from Italy having decreased by $23 \%$. From a business perspective, this raises organizational challenges because as has been outlined previously, Lourdes is "a vast religious complex" (Fargues, 2011, 65) and consequently relies heavily on large-scale pilgrimage groups in relation to the management of processions, religious services and general activities across the Sanctuary. 
This paper contributes by identifying how the challenge of changing patterns of pilgrimage can be addressed. Although many are aware of the objective Grand Miracle of the Lourdes pilgrimage experience (i.e., the apparitions and miraculous cures associated with the shrine), the mini-miracle is less familiar. Consequently, the word-of-mouth storytelling that stimulates and spreads the mini-miracle narrative becomes a crucial driver in maintaining the consumption of the Lourdes pilgrimage experience. Lourdes, as a business institution, should capitalize on the word-of-mouth mini-miracles shared amongst consumers as a means of building and maintaining stronger networks and relationships within Catholic/ Christian communities at both the national and local level. The creation of a national but locally focused online forum where consumers of Lourdes can share their mini-miracle narratives would create useful word-of-mouth marketing and help to build resurgence in the larger pilgrimage groups. Although specific groups and churches run forums and blogs, no alignment currently exists between such groups and Lourdes as an institution. Such marketing activities would require careful management to avoid undermining the sacred nature of the experience, but such online forums may not only increase visitor numbers but would also have the added benefit of creating a supportive community that could enhance the well-being of its members, thereby avoiding a commercial emphasis.

The social transformations Lourdes offers to young consumers generate further managerial implications. Given the life-long loyalty evident among pilgrims towards Lourdes, it is important to capitalize upon, and build a rapport with, this consumer group. Focus upon these consumers will provide the institution with a virtuous circle, not only because they are future consumers but also because their mini-miracle narratives will play a pivotal word-of-mouth role in drawing others to visit.

As with any ethnography, our study is context specific and is not intended to offer generalizable conclusions. However, some similarities may exist across other religious 
marketplaces. Future research should focus on these "place-directed marketplaces" (Scott and Maclaren, 2013) to explore if and how similar transformations of the self occur. 


\section{References}

Ahuvia, A.C. (2005). Beyond the Extended Self: Loved Objects and Consumers Identity Narratives, Journal of Consumer Research, Vol. 32 (1), pp. 171-184.

Arnold, S. and Fischer, E. (1994), “Hermeneutics \& Consumer Research”, Journal of Consumer Research, Vol. 21 No. 1, pp. 55-70.

Arnould, E.J., L.L. Price. (1993), River Magic: Extraordinary Experience and the Extended Service Encounter, Journal of Consumer Research, Vol. 20 (June), 24-44.

Basinger, D. (2011). “What is a miracle?” in Twelftree, G. H. (2011). The Cambridge Companion to Miracles, Cambridge University Press, Cambridge, pp. 36-54.

Belk, R.W. (1988). Possessions \& The Extended Self, Journal of Consumer Research, Vol.15 (2), pp. 139-168.

Belk, R.W., M. Wallendorf, J.F. Jr, Sherry. (1989). The Sacred and the Profane in Consumer Behaviour: Theodicy on the Odyssey, Journal of Consumer Research, Vol. 16 (1), pp. $1-38$.

Brewer, J.D. (1994), “The Ethnographic Critique of Ethnography: Sectarianism in the RUC”, Sociology, Vol. 28 No. 1, pp. 231-244.

Burridge, K. (1960), Mambu, a Melanesian Millennium, Methuen, London, pp. 250.

Celsi, R.L., Rose, R.L. and Leigh, T.W. (1993). Exploration of Leisure Consumption through Skydiving. Journal of Consumer Research, Vol. 20 (1), pp.1-23.

Choi, E.K., Megehee, C.M. (2014), Fashion’s Role in Visualizing Physical and Psychological Transformations in Movies, Journal of Business Research, 67 (1), pp. 2911-2918.

Dunn Ross, E.L., Iso-Ahola, S.E. (1991). Sightseeing Tourists Motivations and Satisfaction, Annals of Tourism Research, Vol. 18 (2), pp. 226-237.

Eade, J. (1992). Pilgrimage and Tourism at Lourdes, France, Annals of Tourism, Vol. 19 (1), pp. 18-32. 
Einstein, M. (2008), Brands of Faith: Marketing Religion in a Commercial Age, London: Routledge.

Fargues, C. (2011). Lourdes, MSM Publications, Lourdes, pp. 224.

Fernandez, K.V., Veer, E. (2004). The Gold that Binds: The Ritualistic Use of Jewelry in A Hindu Wedding, Advances in Consumer Research, Vol. 31 (1), pp.55.

Gesler, W. (1996). Lourdes: Healing in a Place of Pilgrimage, Health and Place, Vol. 2 (2), pp. 95-105.

Granger, K., Lu, V.N., Conduit, J., Veale, R., Habel, C. (2014). Keeping the Faith! Drivers of Participation in Spiritually-Based Communities, Journal of Business Research, Vol. 67 (1), pp. 68-75.

Haddorff, D.W. (2000). Religion and the Market: Opposition, Absorption, or Ambiguity?, Review of Social Economy, Vol. 58 (4), pp. 483-504.

Hamilton, K., Dunnett, S., Downey, H. (2012). Researcher Identity: Exploring the Transformatory power of the research experience, Journal of Consumer Behaviour, Vol. 11 (4), pp. 275-282.

Harris, R. (1999). Lourdes: Cody and Spirit in the Secular Age, Penguin Compass, USA, pp. 473.

Hsu, S-Y., Dehuang, N. and Woodside, A. G. (2009). Storytelling research of consumers' self-reports of urban tourism experiences in China. Journal of Business Research, Vol. 62. Pp. 1223-1254.

Izberk-Bilgin, E. (2013). Theology Meets the Marketplace: The Discursive Formation of the Halal Market in Turkey. In: Rinallo, D., Scott, L. and Maclaren, P., “Consumption and Spirituality”, pp. 41-53. London: Routledge. 
Kedzior, R. (2013). "Materialising the Spiritual: Investigating the role of Marketplace in Creating Opportunities for the Consumption of Spiritual Experiences” in Rinallo, D., Scott, L., Maclaren, P. (2013). Consumption and Spirituality, Routledge, pp. 178-194.

Kniazeva, M., Belk, R.W. (2010). Supermarkets as Libraries of Postmodern Myth, Journal of Business Research, Vol. 63 (1), pp. 748-753.

Larmer (1988), R.A. Water into Wine: An investigation of the concept of Miracle, McGillQueen's University Press, Canada.

Lewis, C.S. (1947/ 2012). Miracles, Harper Collins Publishers, Hammersmith, London, pp. 294.

Lincoln, Y.S. and Guba, E.G. (1985), Naturalistic Inquiry, Beverly Hills, CA: Sage.

Lochran, J. (2008). The Miracle of Lourdes: A Message of Healing and Hope, St. Anthony Messenger Press, Cincinnati, OH, pp.134.

McAlexander, J. H., Leavenworth Dufault, B., Martin, D.M. and Schouten, J. W. (2014), “The Marketization of Religion: Field, Capital, and Consumer identity”, Journal of Consumer Research, Vol 41 No. 3, pp. 858-875.

McCracken, G. (2008). Transformations: Identity Construction in Contemporary Culture, Indiana University Press, Bloomington, IN, pp. 464.

McLeod, W. T., \& Hanks, P. (1982). The New Collins Concise Dictionary of the English Language, William Collins Sons, Glasgow, pp. p. 1388.

Marnham, P. (1982). Lourdes: A Modern Pilgrimage, Image Book Publications, pp. 272.

McDannell, C. (1995). Material Christianity: Religion and Popular Culture in America, Yale University Press, Connecticut, pp. 312.

Morinis, A. (1992). Sacred Journeys: The Anthropology of Pilgrimage, Greenwood Press, Westport, Connecticut, pp. 325.

Moufahim, M. (2013). Religious Gift Giving: An ethnographic account of a Muslim Pilgrimage, Marketing Theory, Vol. 13 (4), pp. 421-441. 
Park, J.Z. and J. Baker. (2007). What Would Jesus Buy: American Consumption of Religious and Spiritual Material Goods, Journal for the Scientific Study of Religion, Vol. 46 (4), pp.501-517.

Penaloza, L. (1994). Atravesando Fronteras / Border Crossings: A Critical Ethnographic Exploration of the Consumer Acculturation of Mexican Immigrants, Journal of Consumer Research, Vol. 21 (1), pp. 32-54.

Penaloza, L., Thompson, C.J., Schouten, J., Sampath, R., Meamber, L. (1998). Just Doing It: A Visual Ethnographic Study of Spectacular Consumption Behavior at Nike Town, Consumption, Markets and Culture, Vol. 2 (4), pp. 337-465.

Reader, I., Walter, T. (1993). Pilgrimage in Popular Culture, The Macmillan press, London, pp. 250.

Rinallo, D., Borghini, S., Bamossy, G., Kozinets, R.V. (2013). "When Sacred Objects Go Brand: Fashion Rosaries and the Contemporary Linkage of Religion and Commerciality” in Rinallo, D., Scott, L., Maclaren, P. (2013). Consumption and Spirituality, Routledge, London, pp. 29-40.

Rook, D.W. (1985). The Ritual Dimension of Consumer Behaviour, Journal of Consumer Research, Vol. 12 (3), pp, 251-264.

Sandikci, O., G. Ger. (2010). Veiling in Style: How Does a Stigmatized Practice Become Fashionable? Journal of Consumer Research, Vol. 37 (1), pp. 15-36.

Schembri, S. (2009). Reframing brand experience: The experiential meaning of HarleyDavidson, Journal of Business Research, Vol. 62, pp. 1299-1310.

Schouten, J.W., McAlexander, J.H. (1995). Subcultures of Consumption: An Ethnography of the New Bikers, Journal of Consumer Research, Vol.22 (3), pp. 43-61. 
Scott, L., Maclaren, P. (2013). "Consuming the Mists and Myths of Avalon: A Case Study of Pilgrimage in Glastonbury” in Rinallo, D., Scott, L., Maclaren, P. (2013). Consumption and Spirituality, Routledge, London, pp. 195-207.

Sherry, J.F. (1998). Servicescapes: The Concept of Place in Contemporary Markets, American Marketing Association, Chicago, pp. 632.

Spiggle, S. (1994), “Analysis and Interpretation of Qualitative Data in Consumer Research”, Journal of Consumer Research, Vol. 21, No. 3, pp. 491-503.

Tiwsakul, R.A., Hackley, C. (2010). Postmodern Paradoxes in Thai-Asian Consumer Identity, Journal of Business Research, Vol. 65 (1), pp. 490-496.

Twitchell, J. B. (2005), Branded Nation: The Marketing of Megachurch, College Inc., and Museumworld, London: Simon and Schuster.

Turner, V., Turner, E.L.B. (1978). Image \& Pilgrimage in Christian Culture, Columbia University Press, New York, pp. 281.

Turley, D. (2013). Forming Sacred Places and Possessions: Pilgrims at St. Brigid’s Holy Well. In: Rinallo, D., Scott, L. and Maclaren, P., “Consumption and Spirituality”, pp. 165-177. London: Routledge.

Urry, J. (1995) Consuming Places. London: Routledge.

Wallendorf, M., Belk, R.W. (1989). “Assessing Trustworthiness in Naturalistic Consumer Research” in Hirschman, E.C. (1989). Interpretive Consumer Research, pp. 69-84. 
Table 1: Table of Respondents

\begin{tabular}{|c|c|c|c|c|}
\hline Name & Age & Occupation & $\begin{array}{l}\text { No of Times } \\
\text { to Lourdes }\end{array}$ & $\begin{array}{l}\text { Individual or Group } \\
\text { Interview }\end{array}$ \\
\hline Danielle & 18 & Student & First Time & Individual \\
\hline Frances & 17 & Student & First Time & Individual \\
\hline Brendan & 73 & Priest & $\begin{array}{l}\text { Lives in } \\
\text { Lourdes }\end{array}$ & Individual \\
\hline Kelly & 35 & $\begin{array}{l}\text { Secondary } \\
\text { school teacher }\end{array}$ & 6 & Individual \\
\hline Lisa & 19 & Student & 5 & Individual \\
\hline Lilly & 24 & $\begin{array}{l}\text { Primary school } \\
\text { teacher }\end{array}$ & 7 & Individual \\
\hline Miriam & 25 & $\begin{array}{l}\text { Marketing } \\
\text { Assistant }\end{array}$ & 11 & Individual \\
\hline Matthew & 22 & Student & 5 & Individual \\
\hline Marie & 54 & Historian & $50+$ & Individual \\
\hline Patricia & 93 & Retired & $60+$ & Individual \\
\hline Paul & 63 & $\begin{array}{l}\text { Secondary } \\
\text { School teacher }\end{array}$ & 10 & Individual \\
\hline Phillip & 61 & Business man & $21+$ & Individual \\
\hline Pierre & 40 & $\begin{array}{l}\text { Hotel Chain } \\
\text { Owner }\end{array}$ & $\begin{array}{l}\text { Lourdes } \\
\text { Native }\end{array}$ & Individual \\
\hline Sr. Anne & 37 & Nun & 8 & Individual \\
\hline Garry & 25 & $\begin{array}{l}\text { Secondary } \\
\text { school teacher }\end{array}$ & 6 & $\begin{array}{l}\text { Group (with his brother } \\
\text { Jacob) }\end{array}$ \\
\hline Jacob & 27 & $\begin{array}{l}\text { Primary School } \\
\text { teacher }\end{array}$ & 12 & $\begin{array}{l}\text { Group (with his brother } \\
\text { Garry) }\end{array}$ \\
\hline Veronica & 60 & Retired & 11 & $\begin{array}{l}\text { Group (with her husband } \\
\text { James) }\end{array}$ \\
\hline James & 63 & Doctor & 11 & $\begin{array}{l}\text { Group (with his wife } \\
\text { Veronica) }\end{array}$ \\
\hline Christine & 63 & Retired & 13 & $\begin{array}{l}\text { Group (with her friends and } \\
\text { fellow pilgrims) }\end{array}$ \\
\hline Kitty & 66 & Retired & 10 & $\begin{array}{l}\text { Group (with her friends and } \\
\text { fellow pilgrims) }\end{array}$ \\
\hline Rachael & 74 & Retired & 10 & $\begin{array}{l}\text { Group (with her friends and } \\
\text { fellow pilgrims) }\end{array}$ \\
\hline
\end{tabular}

